\title{
PLATONIZM A SPÓR O UNIWERSALIA W ZWIĄZKU Z KSIĄŻKĄ PAWŁA ROJKA TROPY I UNIWERSALIA**
}

\begin{abstract}
Platonism and the Problem of Universals: A Polemic with Pawee Rojek's TROPY I UNIWERSALIA (TROPES AND UNIVERSALS)

This paper is a polemic with Paweł Rojek's criticism of Platonism as one of the positions concerning universals. The problem of universals is taken to be about the basis of resemblance between things. Rojek maintains that Platonism is a hidden form of nominalism. Section 1 presents my understanding of the key terms concerning the controversy. Section 2 shows that Rojek's argument begs the question: he simply presupposes that only a moderate realist has a correct concept of universal. In section 3, I argue that the Platonist argument for the transcendence of universals is valid, and I criticize Rojek's responses to the separation argument against moderate realism. Finally, section 4 demonstrates that the transcendence of universals is compatible with their generality.

Keywords: Platonism, universals, transcendence, inseparability, the problem of resemblance
\end{abstract}

\section{WPROWADZENIE}

Artykuł jest polemiką z krytyką platonizmu przedstawioną przez Pawła Rojka w książce Tropy $i$ uniwersalia (Rojek 2019; por. Luc 2020). Polemiki tej nie wiążę jednak z żadnym argumentem na rzecz platonizmu. Nie chcę rozstrzygać tytułowego sporu. Chcę jedynie pokazać, że platonizm jest jednym z sensownych realistycznych rozwiązań sporu o powszechniki rozumianego jako spór o podstawę podobieństwa między rzeczami.

* Wydział Filozofii, Katolicki Uniwersytet Lubelski Jana Pawła II, Al. Racławickie 14, 20-950 Lublin, e-mail: marek.piwowarczyk@kul.pl, ORCID: https://orcid.org/oooo-ooo30112-8738.

** Dziękuję anonimowemu recenzentowi za uwagi, które pozwoliły ulepszyć artykuł. 
Podobieństwo to jest aspektualne. Pomidor jest podobny do papryki nie całym sobą, lecz pod pewnymi względami, na przykład koloru czy masy. Te aspekty podobieństwa mogą być własnościami - i tak właśnie jest w przypadku koloru i masy - ale mogą też być istotami przedmiotów. Zosia jest podobna do Jana przede wszystkim ze względu na swą istotę: człowieczeństwo. Podobieństwo pomidora i papryki nie jest tak daleko idące: dotyczy tylko własności, a nie istot. Ostatecznie chodzi więc o podstawę podobieństwa między istotami rzeczy i podobieństwa między własnościami rzeczy. Stąd za właściwą formę platonizmu uważam tę, w której uniwersaliami są tzw. jakości idealne (np. idealne człowieczeństwo lub idealna czerwień), pod które podpadają istoty i własności (np. człowieczeństwo Jana lub czerwień pomidora). Jakości takie nie są czymś, pod co podpadają przedmioty, np. sama Zosia lub Jan, lecz czymś, pod co podpadają aspekty przedmiotów. Innymi słowy, $\mathrm{w}$ artykule rozważam taką wersję platonizmu, w której uniwersaliami są idealne jakości, a nie idealne przedmioty. Powszechnikiem jest np. idealne człowieczeństwo, a nie idealny człowiek.

Przez uniwersale rozumiem taki byt, który stanowi podstawę podobieństwa jakichś innych bytów przez to, że owe byty odnoszą się do niego w dokładnie taki sam sposób. Nie przesądzam w tym artykule, na czym ma polegać to odniesienie. Może to być platońskie uczestnictwo w powszechniku (realizm skrajny, czyli platonizm) albo należenie do zbioru (nominalizm teoriomnogościowy), albo bycie częścią powszechnika (nominalizm mereologiczny), albo zawieranie w sobie powszechnika (realizm umiarkowany, czyli immanentny), albo jeszcze coś innego. Zawsze jednak powszechnik musi być czymś, w czym ugruntowane jest podobieństwo. Konsekwentny nominalizm jest stanowiskiem uznającym pierwotność podobieństwa.

Idealnym nazywam taki byt, który nie istnieje w żaden sposób w czasie i przestrzeni. Nie chodzi tylko o to, że byt ów nie ma czasoprzestrzennej rozciągłości, ale o to, że nie jest też żadnym (nawet nierozciągłym) aspektem przedmiotów czasoprzestrzennych. $\mathrm{W}$ związku z tym byty idealne są niezmienne i nie wchodzą w związki przyczynowe, o ile za człony związków przyczynowych uznajemy zdarzenia, procesy lub rzeczy trwające w czasie. Idealność nie pociąga za sobą uniwersalności (ogólności), zatem są możliwe idealne partykularia (np. idealne kwadraty, liczby itd.).

Partykulare (byt jednostkowy) to coś, co nie jest powszechnikiem. Innymi słowy, partykulare to coś, pod co już nic innego nie podpada; coś, co nie jest już podstawą podobieństwa; coś, co nie odnosi się do innych bytów dokładnie w ten sam sposób. Bytami jednostkowymi mogą być zarówno przedmioty konkretne, np. Zosia, Jan, drzewo, logarytm naturalny $e$, jak i abstrakcyjne, np. czlowieczeństwo Zosi, muzykalność Jana, stabilność drzewa, bycie równym jednej 
z liczb pierwszych (własność ln $e$ ). Przez abstrakcyjność rozumiem bowiem niesamodzielność względem czegoś innego, a więc konieczność istnienia wyłącznie w obrębie szerszej całości, a przez konkretność rozumiem samodzielność, a więc niekonieczność bycia składnikiem większej całości. Własności i istoty są abstrakcyjnymi partykulariami, a „pełne” przedmioty są konkretnymi partykulariami.

Termin ,jakość idealna” został zapożyczony z ontologii Romana Ingardena, który wolał używać terminu „czysta jakość idealna”. Trzeba przy tym zaznaczyć, że Ingarden raczej nie zgodziłby się z tezą, że to idealne jakości są uniwersaliami, ponieważ za byty ogólne uważał idee. Idee są według Ingardena przedmiotami o dwustronnej budowie (Ingarden 1987a: 49-55; 1987b: 211-250). Jedna strona to idea jako idea, której przysługują specyficzne własności, np. idealność. Druga strona to zawartość idei. Składają się na nią idealne konkretyzacje (można powiedzieć instancje, egzemplifikacje) czystych jakości idealnych bądź idealne konkretyzacje możliwości konkretyzacji czystych jakości. Tę bardzo zawiłą charakterystykę zawartości idei lepiej przedstawić na przykładzie. W zawartości idei człowieka występują idealne konkretyzacje takich czystych jakości, jak człowieczeństwo, wolitywność, rozumność, zdolność do śmiechu itp. Są one nazywane stałymi idei człowieka. Oprócz stałych możemy odnaleźć również zmienne: jakiś kolor skóry, jakąś wrażliwość na muzykę itp. O ile stałe są sztywno ustalone, o tyle zmienne przewidują jedynie pewien zakres jakości. Żeby być człowiekiem, trzeba mieć wolę, i dlatego w idei człowieka idealna konkretyzacja wolitywności jest stałą. Trzeba mieć też pewien kolor skóry, ale on może być różny. Dlatego też ten aspekt stanowi zmienną zawartości idei. Żadna z jakości znajdujących się w zawartości idei nie jest własnością ani istotą tej idei jako idei. Idea człowieka nie jest człowiekiem ani nie ma koloru i inteligencji.

Przedmiot jednostkowy podpada pod ideę w tym sensie, że konkretyzują się w nim jakości występujące w zawartości idei. Nietrudno jednak zauważyć, że w ten sposób konkretyzują się w przedmiocie jednostkowym również same czyste jakości idealne, tyle że ta konkretyzacja jest zapośredniczona przez idee.

Wróćmy teraz do problemu uniwersaliów. Ingarden powiedziałby zapewne, że Zosia jest podobna do Jana dlatego, że oboje podpadają pod tę samą ideę człowieka. Niemniej, musimy pamiętać o aspektualności podobieństwa. Trzeba zatem uznać, że jest ono zapewnione przez to, że w Zosi i Janie konkretyzują się te same jakości, które występują w idei człowieka. Te ostatnie są jednak idealnymi konkretyzacjami czystych jakości, stąd tak naprawdę można pominąć pośredni etap idei i od razu powiedzieć, że Zosia i Jan są podobni pod pewnymi względami, ponieważ konkretyzują się w nich te same czyste jakości idealne. Do rozwiązania problemu uniwersaliów idee są zbędne. Być może z innych powodów musimy przyjąć również idee rzeczy, ale one i tak nie stanowiłyby ostatecznej podstawy podobieństwa. Zgadza się z tym również Rojek (2019: 145). 


\section{PLATONIZM JAKO NOMINALIZM?}

Według Rojka każdy platonizm jest ukrytym nominalizmem (Rojek 2019: 53). Dla Rojka nominalizmem jest bowiem każde rozwiązanie sporu, które przeczy tezie, że rzeczy mają wspólne własności (lub istoty) bądź aspekty własności (lub istot ${ }^{1}$ ). Tylko takie istoty, własności lub ich aspekty są powszechnikami. „Wspólne” w tym kontekście znaczy: „w całości obecne w wielu rzeczach jednostkowych naraz". Gdy widzimy czerwonego pomidora i czerwoną paprykę, to zgodnie z tym poglądem widzimy dwa podmioty własności, ale tylko jedną czerwień. Innymi słowy, czerwień pomidora jest literalnie (numerycznie) identyczna z czerwienią papryki. Jeśli nie godzimy się na to, że w pełni określone własności mogą być immanentne wielu rzeczom naraz, to możemy przejść na nieco słabsze pozycje i twierdzić, że jedynie niedookreślone aspekty własności są identycznie te same w wielu przedmiotach. Chodzi o takie aspekty jak barwność albo czerwień jako taka, to znaczy czerwień wyabstrahowana od szczególnego odcienia (np. karmazynu bądź minii), nasycenia, jasności itp. Takie niedookreślone aspekty nazywa się determinabiliami. Rojek wydaje się mieć więcej sympatii dla koncepcji głoszącej, że determinabilia są powszechnikami, niż dla koncepcji, że są nimi w pełni określone własności. Nie zmienia to jednak jego rozumienia powszechnika.

Platonik wierzy, że uniwersalia są idealne. Nawet więcej: uważa, że uniwersalia są transcendentne względem wszelkiego rodzaju rzeczy jednostkowych - również jednostkowych przedmiotów idealnych. Nie mogą więc być całe obecne w wielu rzeczach naraz. Dla platonika ogólna czerwień nie istnieje $\mathrm{w}$ czasoprzestrzeni ani nie jest w żadnym sensie składnikiem czasoprzestrzennych czerwonych rzeczy. Podobnie idealna kwadratowość jest transcendentna wobec jednostkowych idealnych kwadratów. Ogólność to dla platonika również pewnego rodzaju wspólność, ale ta ostatnia nie jest rozumiana jako identyczność istot bądź własności zawierających się w wielu przedmiotach. Według zwolennika platonizmu uniwersalia są jedynie wspólnym punktem odniesienia dla podpadających pod nie partykulariów (jednostkowych istot i własności) (Rosiak 2012: 149). Uniwersalia odnoszą się w dokładnie taki sam sposób do rzeczy jednostkowych, ale pozostają względem nich transcendentne. Stąd według Rojka platońskie uniwersalia są jedynie pozornie uniwersaliami, a platonizm jest jedynie pozornym realizmem.

Pierwsze, co przychodzi na myśl w związku z tak zarysowanym rozumowaniem, to to, że oparte jest ono na błędzie petitio principii. Rojek zakłada po prostu pewną definicję uniwersale i w jej świetle ocenia pozostałe koncepcje

${ }^{1}$ Ze względów stylistycznych nie będę za każdym razem dodawal, że chodzi również o istoty rzeczy. 
uniwersaliów. Jego rozumienie powszechnika jest swoiste dla realizmu umiarkowanego (można go też nazwać immanentnym). Stąd nominalizmem jest wtedy każda teoria, która nie jest jakąś formą realizmu umiarkowanego.

Rojek uznaje swoje rozumienie powszechnika za jedyne właściwe, ponieważ uważa, że w sporze o uniwersalia trzeba przyjąć tzw. zakresowe pojęcie powszechnika (Rojek 2019: 27-31). Odpowiada ono temu, co powiedziano wyżej (powszechnik to dosłownie wspólna istota, własność bądź aspekt istoty lub własności) i przeciwstawione jest tzw. funkcjonalnemu pojęciu powszechnika (Rojek 2019: 31-34). To ostatnie można z grubsza określić następująco: powszechnikiem jest coś, co rozwiązuje problem powszechników. Problem ten miał wiele odsłon w historii filozofii, ale Rojek wybiera jedną z nich, wyrażaną pytaniem: co jest podstawą podobieństwa między rzeczami? Zatem powszechnik w sensie funkcjonalnym to podstawa podobieństwa między rzeczami.

Nietrudno zauważyć, że we wprowadzeniu do tego artykułu przyjęto właśnie funkcjonalne pojęcie powszechnika. Rojek słusznie zauważa, że podstawa podobieństwa wcale nie musi być dosłownie wspólnym składnikiem wielu rzeczy. Twierdzi jednak, że gdy przyjmiemy funkcjonalne rozumienie powszechnika, to niektóre z bytów uznanych za uniwersalia wcale nie będą mieć cechy ogólności, oraz że wówczas wszystkie stanowiska w sporze będą postulować istnienie jakichś uniwersaliów.

Nerwem argumentacji na rzecz tej pierwszej tezy jest analogia do sporu o światy możliwe. Zarówno David Lewis, jak i Alvin Plantinga twierdzą, że światy możliwe istnieją, ale dla Lewisa nie są one wcale możliwe, lecz faktycznie zrealizowane - są po prostu czasoprzestrzennymi, konkretnymi światami różnymi od naszego i istniejącymi równolegle z nim. Nie jest tak, że mogą dopiero zaistnieć (jeśli bierzemy pod uwagę możliwość temporalną) albo że są czymś, co mogłoby istnieć, ale jednak nie istnieje (możliwość kontrfaktyczna). Światy Plantingi są zaś możliwe w tym właśnie sensie. Są one czymś niezrealizowanym, nie są faktyczne, ale są możliwe w „prawdziwym” sensie tego słowa. W podobny sposób, według Rojka, platońskie uniwersalia nie są rzeczywiście czymś ogólnym, tylko są pewnymi bytami jednostkowymi. Dlaczego? Ponieważ nie są dosłownie wspólnymi składnikami rzeczy jednostkowych. Znów wygląda to na petitio principii. Dlaczego bowiem mamy rozumieć ogólność powszechnika w ten właśnie sposób? Oczywiście platonik zgodzi się z tezą, że jego uniwersalia nie są ogólne w sensie założonym przez Rojka. Nie zgodzi się jednak, że do ogólności konieczna jest immanencja: owszem, powszechnik jest czymś, co jest wspólne dla wielu rzeczy, tzn. jednostkowe rzeczy odnoszą się dokładnie w taki sam sposób do jakiegoś jednego identycznego bytu i dzięki temu są podobne, ale to odnoszenie się nie może być rozumiane jako zawieranie tego bytu. Czemu jednak mamy wybrać Rojka rozumienie ogólności jako to właściwe? 
Odpowiedzi na to pytanie nie odnajdziemy w Tropach $i$ uniwersaliach. Autor poświęca jednak nieco miejsca na pokazanie, że przyjęcie funkcjonalnego pojęcia powszechnika prowadzi do wniosku, że każde stanowisko w sporze o uniwersalia jest jakimś realizmem. Nie będę analizował szczegółowych rozważań Rojka, natomiast skupię się na pokazaniu w inny sposób, że broniona przez niego teza jest fałszywa.

Na pierwszy rzut oka mogłoby się wydawać, na przykład, że dla nominalisty tropowego każda jednostkowa własność czy istota jest powszechnikiem, ponieważ każda taka własność odnosi się w ten sam sposób do innych podobnych do niej własności i tym sposobem odniesienia jest doskonałe podobieństwo. Niemniej, nominalista tropowy nie będzie twierdzil, że czerwień pomidora jest doskonale podobna do czerwieni papryki dlatego, że obie są doskonale podobne do, dajmy na to, czerwieni jabłka (zakładam, że w każdym przypadku są to nieodróżnialne jakościowo czerwienie o tej samej jasności, nasyceniu i odcieniu). Żadna z jednostkowych własności nie jest podstawą podobieństwa dla innych jednostkowych własności.

Ktoś mógłby jednak powiedzieć, że pomimo tego, to właśnie jednostkowe własności są podstawą swojego podobieństwa do innych własności. Podobieństwo czerwieni jabłka, czerwieni pomidora i czerwieni papryki zachodzi dzięki tym właśnie czerwieniom, a więc każda z nich jest podstawą podobieństwa i każda z nich odnosi się w jednakowy sposób do innych. Taka sytuacja wydaje się spełniać funkcjonalną definicję powszechnika.

Myślę, że byłoby to rozumowanie oparte na wieloznaczności terminu „bycie podstawą”. Owszem, jednostkowe własności są podstawą doskonałego podobieństwa, ale jedynie $\mathrm{w}$ taki sposób, $\mathrm{w}$ jaki wszystkie fundamenty relacji są podstawami relacji. Czerwień jabłka i czerwień pomidora są podstawami swego podobieństwa $w$ tym sensie, że bez tych dwu czerwieni nie zaistniałaby w ogóle żadna relacja między nimi. Jest też tak, że obie czerwienie „same z siebie" wystarczają do zachodzenia podobieństwa, ale to znaczy tylko tyle, że podobieństwo miedzy nimi jest pierwotne, tzn. nieugruntowane, niezapośredniczone już w niczym innym. Natomiast w problemie uniwersaliów chodzi właśnie o to, czy podobieństwo jest z konieczności zapośredniczone i jeśli tak, to w jakiej innej relacji. Uniwersale to coś, co koniecznie zapośrednicza podobieństwo, i w tym sensie jest jego podstawą ${ }^{2}$. Dlatego żadna jednostkowa własność nie może być uniwersale. Mimo że jednostkowe czerwienie są w wy-

\footnotetext{
${ }^{2}$ Nieraz mówi się, że nominalizm w sensie źródłowym polega na tym, że słowa uznaje się za uniwersalia, a więc że jest on jakimś realizmem, ponieważ postuluje uniwersalia, ale umieszcza je w sferze języka. Zauważmy jednak, że tak pojęty nominalizm był prawdopodobnie odpowiedzią na inny problem: czy wyrażeniom ogólnym odpowiadają jakieś ogólne przedmioty. W żadnym sensie słowa nie mogą być podstawami podobieństwa rzeczy.
} 
łuszczonym przed chwilą sensie podstawami swego podobieństwa do innych czerwieni, to jednak nadal nie jest tak, że czerwień pomidora jest podobna do czerwieni papryki dzięki ich wspólnemu podobieństwu do czerwieni jabłka. Ta ostatnia mogłaby w ogóle nie istnieć, a i tak zachodziłoby podobieństwo między dwiema pierwszymi czerwieniami. Stąd nominalizm tropowy nie jest w żadnym sensie realizmem w kwestii powszechników3. Nie będzie nim też żadna z teorii uznająca podobieństwo za pierwotne.

Fiasko różnych odmian realizmu można ukazać jedynie przez zbadanie, czy powszechniki postulowane przez te realizmy rzeczywiście mogą w spójny sposób zapośredniczać relację podobieństwa. Rojek powinien najpierw zbadać, czy pojęta po platońsku ogólność uniwersaliów umożliwia im bycie podstawą podobieństwa, a nie z góry odrzucać taką możliwość jedynie z tego powodu, że platońskie uniwersalia nie są ogólne w sensie realizmu umiarkowanego.

Wydaje się, że Rojek nie zauważa kolistego charakteru swej argumentacji dlatego, że nieświadomie popełnia inny błąd. Termin „spór o uniwersalia” ma u niego dwa znaczenia. Raz jest rozumiany jako problem wyrażany pytaniem „czy istnieje i jaka jest podstawa podobieństwa między rzeczami?”, a innym razem jako problem odpowiadający pytaniu „czy istnieją wspólne własności immanentne rzeczom?”. Oczywiście te zagadnienia wiążą się ze sobą: drugie jest częścią pierwszego. Jednak Rojek wydaje się je utożsamiać. W takiej sytuacji łatwo pomyśleć, że skoro ktoś odpowiada negatywnie na drugie pytanie, to również negatywnie rozwiązuje pierwszy spór. Rojek mógłby oczywiście napisać książkę o fragmencie problemu uniwersaliów, która dotyczyłaby drugiego problemu, ale nawet wtedy nie powinien twierdzić, że wszystkie odpowiedzi negatywne na postawione pytanie są nominalizmami. Żeby to stwierdzić, trzeba byłoby rozwiązać pozostałe fragmenty sporu. Jeśli jednak ktoś stawia problem uniwersaliów explicite $\mathrm{w}$ pierwszej formie, to powinien pogodzić się z tym, że a limine nie można wykluczyć możliwości realistycznych rozwiązań sporu innych niż realizm umiarkowany, a więc że nie można wykluczyć, iż powszechnikiem może być coś, co nie jest dosłownie wspólnym składnikiem wielu rzeczy.

Jeśli problem uniwersaliów wyraża pytanie o podstawę podobieństwa, to należy przyjąć funkcjonalne pojęcie powszechnika. Odrzucenie go prowadzi do błędu petitio principii. Niestety, czytając fragmenty poświęcone Platonowi, odnosi się wrażenie, że Rojek ten błąd popełnia: „paradoksalnie, ze wszystkich rodzajów realizmu to właśnie platonizm wydaje się najbardziej wątpliwy, ponieważ idee, które są transcendentne, nie są właściwie powszechnikami,

${ }^{3}$ Rojek niesłusznie nazywa nominalizm tropowy „nominalizmem umiarkowanym”. Nominalista tropowy nie czyni przecież żadnego ustępstwa na rzecz realizmu, to znaczy, nie przyjmuje nawet jakiejś słabej postaci uniwersaliów. 
czyli czymś, co jest rzeczywiście jedno w wielości” (Rojek 2019: 49). Omawiając Platoński argument przeciw tezie, że idee są całe sobą obecne w wielu rzeczach, Rojek pisze:

Platon odrzuca w tym miejscu fundamentalne założenie, że własności mogą być w wielu rzeczach naraz, to znaczy „oddzielone od siebie”, i dochodzi do wniosku, że nie ma w ogóle niczego takiego, co byłoby czymś jednym, w czym uczestniczyłoby wiele różnych rzeczy [...]. „Dokładnie w tym miejscu - pisał z oburzeniem Donald Brownstein [...] - Platon poddaje się i zostaje nominalistą". Tego faktu nie zmienia to, że Platon przyjmuje całą sferę transcendentnych idei (Rojek 2019: 54).

We fragmentach dotyczących Ingardena jest podobnie:

Ingarden rozumiał relację konkretyzacji czystych jakości idealnych przez własności wyłącznie jako zewnętrzne przyporządkowanie elementów świata realnego i elementów świata idealnego. Jakości idealne - jak stwierdzał z naciskiem - w żadnym sensie nie uczestniczą w swoich realizacjach. Skoro tak, to niestety nie są uniwersaliami. Nie są one czymś, co jest czymś jednym i zarazem w wielu rzeczach, lecz doskonale jednostkowymi i niepowtarzalnymi bytami (Rojek 2019: 164).

Zarzut popełnienia petitio principii przez Rojka można jednak nieco osłabić. Ostatni cytat świadczy o tym, że transcendencję platońskich uniwersaliów rozumie on, sugerując się wypowiedziami Ingardena, wyłącznie jako „zewnętrzne przyporządkowanie”. Jeśli to zewnętrzne przyporządkowanie polegać by miało na braku istotnego związku między partykulariami a uniwersaliami (a tak pojmuje je Rojek), to wtedy miałby rację, twierdząc, że platońskie rozumienie powszechnika nie wystarcza do tego, aby rozwiązać zagadnienie uniwersaliów. Problem jednak w tym, czy rzeczywiście transcendencja platońskich uniwersaliów pociąga za sobą brak istotnego związku zapewniającego podstawę podobieństwa. Prześledźmy zatem problem transcendencji uniwersaliów.

\section{TRANSCENDENCJA POWSZECHNIKÓW}

\subsection{NOWA POSTAĆ ARGUMENTU Z ODDZIELENIA}

Najważniejszy platoński argument na rzecz transcendencji uniwersaliów to argument z oddzielenia, wspominany już (choć nie z nazwy) wyżej. Opiera się on na następującym dylemacie: jeśli uniwersale miałoby być $\mathrm{w}$ całości

\footnotetext{
4 Nazwa „argument z oddzielenia” może być myląca. Nieraz argumentu o tej nazwie używa się przeciw platonizmowi, twierdząc, że z powodu swego oddzielenia platońskie powszechniki nie mogą odgrywać żadnej roli w świecie bytów jednostkowych. Tutaj chodzi jednak o coś innego: powszechnik nie może być immanentny wielu rzeczom naraz, ponieważ wtedy musiałby być oddzielony od samego siebie.
} 
obecne $\mathrm{w}$ wielu rzeczach jednostkowych naraz, to albo te rzeczy byłyby ze sobą połączone, albo uniwersale byłoby oddzielone od samego siebie. Obie możliwości wydają się nie do przyjęcia. Argument ten jest w istocie skierowany przeciwko realizmowi umiarkowanemu. Jest też powszechnie ignorowany przez zwolenników tego stanowiska, a to z tej przyczyny, że oddzielenie i połączenie rozumieją oni $\mathrm{w}$ kategoriach przestrzennych, twierdząc przy tym (słusznie), że własności (utożsamiane przez nich z powszechnikami) nie istnieją $\mathrm{w}$ przestrzeni tak samo jak przedmioty określone własnościami i dlatego własności mogą pozwolić sobie na bycie $\mathrm{w}$ wielu miejscach naraz (co już prawdą nie jest).

Niekiedy jednak rozumie się oddzielenie i połączenie jako, odpowiednio, samodzielność i niesamodzielność egzystencjalną (Piwowarczyk 2014, 2015: 173-180). Są to pojęcia Ingardenowskiej ontologii egzystencjalnej (Ingarden 1987a: 116-121). Modyfikując nieco oryginalne sformułowania Ingardena, powiemy, że $x$ jest niesamodzielny względem $y$ wtedy i tylko wtedy, gdy z istoty $x$ wynika, że musi wspólistnieć z $y$ w obrębie jednej całości zjednoczonej związkiem formalnym (Piwowarczyk 2020). Związek formalny nie jest regularną relacją, tzn. nie jest dodatkową treścią relacyjną „wciśniętą" między swoje człony (taką jak np. braterstwo lub miłość). Tego typu „nierelacyjne węzły” postulowane są przez wielu filozofów w celu uniknięcia regresu Bradleya (Rojek 2019: 74). Związek formalny nie jest dodatkowym bytem relacyjnym łączącym jakieś dwa inne byty, lecz jest jedynie formą bezpośredniego wspólistnienia tych bytów. Jedność zapewniona przez regularną relację jest zawsze jednością zapośredniczoną przez tę relację, natomiast jedność uzyskana dzięki związkowi formalnemu jest bezpośrednia. Dla przykładu, związek między własnością i jej podmiotem jest związkiem formalnym. Nie jest potrzebna żadna dodatkowa treść, która łączyłaby własność z podmiotem. Gdyby tak było, to potrzebowalibyśmy kolejnych treści łączących ową dodatkową treść z podmiotem z jednej strony i z własnością z drugiej. Prowadziłoby to do regresu w nieskończoność.

Niesamodzielność może być sztywna lub rodzajowa. Sztywna jest wtedy, gdy zachodzi względem bytu określonego co do indywidualnej tożsamości. $\mathrm{Z}$ niesamodzielnością rodzajową mamy do czynienia wtedy, gdy przedmiot musi współistnieć $\mathrm{w}$ obrębie formalnej całości z jednym dowolnym przedmiotem należącym do określonego rodzaju. Dla przykładu, sądzę (wbrew realistom umiarkowanym), że każda moja własność jest sztywno niesamodzielna wobec mnie, tzn. nie może zacząć przysługiwać innemu podmiotowi. Ja sam z kolei jestem rodzajowo niesamodzielny wobec kształtów: jakiś kształt muszę mieć, ale niekoniecznie ten, który mam w tej chwili. W danym momencie mogę jednak mieć tylko jeden kształt, podobnie jak np. jedną wartość masy. Niesamodzielność rodzajową najlepiej przedstawić na przykładzie własności przy- 
godnych: mogę utracić pewną własność pod warunkiem, że jej miejsce zajmie druga tego samego rodzaju - miejsca koloru nie może zająć kształt.

Niesamodzielność może być wzajemna lub jednostronna. Samodzielność jest zaprzeczeniem niesamodzielności: $x$ jest samodzielny względem $y$ wtw, gdy z istoty $x$ wynika, że $x$ nie musi wspólistnieć z $y$ w obrębie jednej całości powiązanej związkami formalnymi. Samodzielne przedmioty mogą jednak ze swej istoty potrzebować innych przedmiotów do istnienia. Mówimy wtedy o nich, że są zależne od tych przedmiotów (Ingarden 1987a: 121-123). Należy więc rozróżnić niesamodzielność i zależność. Wzajemnie zależne byty też mogą tworzyć całość, ale nie będzie to całość zjednoczona związkami formalnymi, tylko regularnymi koniecznymi relacjami. Całość powiązana regularnymi relacjami jest nazywana całością relatywną bądź sumatywną.

Argument $\mathrm{z}$ oddzielenia sformułowany za pomocą pojęć samodzielności i niesamodzielności będzie wyglądał w skrócie tak: jeśli uniwersale byłoby $\mathrm{w}$ całości obecne $\mathrm{w}$ wielu rzeczach naraz, to albo te rzeczy byłyby względem siebie niesamodzielne, albo uniwersale byłoby samodzielne względem siebie. Obie możliwości są nie do przyjęcia. Pierwsza prowadzi do pewnego rodzaju monizmu, a druga jest absurdalna sama w sobie. W takiej formie argument dotyczyłby nie tylko rzeczy czasoprzestrzennych, lecz także ewentualnie idealnych przedmiotów jednostkowych. Nie można też go odrzucić na podstawie przekonania o swoistym stosunku własności do przestrzeni, ponieważ oddzielenie i połączenie nie są tu w ogóle rozumiane przestrzennie.

\subsection{ZAGROŻENIE MONIZMEM}

Zacznijmy od pierwszej części dylematu. Zakładam, zgodnie z duchem realizmu umiarkowanego, że egzemplifikowanie uniwersale przez przedmiot jednostkowy polega na tym, że przedmiot jest podmiotem uniwersale, a ono jego własnością (cechą), lub też - co na to samo wychodzi - że uniwersale inheruje w przedmiocie. Pociąga to za sobą immanencję uniwersale w przedmiocie jednostkowym. Immanencję tę rozumiem nie $\mathrm{w}$ kategoriach przestrzennych, lecz jako niesamodzielność uniwersale względem przedmiotu i na odwrót5. Niech przedmioty $a$ i $b$ egzemplifikują uniwersale $F$. Wtedy $a$ jest niesamodzielne wobec $F$, a $F$ jest niesamodzielne wobec $b$, zatem $a$ jest niesamodzielne wobec $b$. Można to rozszerzyć na wszystkie przedmioty egzemplifikujące $F$ oraz na inne uniwersalia egzemplifikowane przez te przedmioty. Wówczas np. wszystkie rzeczy soczyste będą należeć do pewnej całości powią-

\footnotetext{
${ }^{5}$ Kwestia niesamodzielności podmiotu względem powszechnika zostanie sproblematyzowana i wyjaśniona niżej.
} 
zanej związkami formalnymi. Do tej całości będzie również należeć soczystość. Całość ta, o ile już sama jest samodzielna, będzie wtedy konkretem, a przedmioty i uniwersalia do niej należące będą abstraktami. Można nazwać taki pogląd „lokalnym monizmem” - lokalnym, ponieważ dotyczącym tylko przedmiotów egzemplifikujących dane uniwersale. Jeśli istnieją takie uniwersalia, które są egzemplifikowane przez wszystkie przedmioty, to otrzymamy monizm globalny.

Przedstawiony argument zakłada, że niesamodzielność między przedmiotami jednostkowymi a uniwersaliami jest przechodnia i wzajemna. Rojek, dla którego realizm umiarkowany jest paradygmatem realizmu w kwestii uniwersaliów, atakuje przechodniość niesamodzielności: „z tego, że $a$ tworzy jedną całość z $F$ i $F$ tworzy jedną całość z $b$, nie wynika, że $a$ tworzy jedną całość z $b$, lecz tylko tyle, że całości, do których należą $a$ i $b$, mają wspólną część" (Rojek 2019: 134). Oczywiście jest prawdą, że całość $(F, a)$ jest różna od całości $(F, b)$, ale również prawdą jest, że byty $F, a$ i $b$ ze swej istoty wspólistnieją $\mathrm{w}$ obrębie formalnie zjednoczonej całości $(F, a, b)$ i ta sytuacja spełnia definicję niesamodzielności. Rojek myli niesamodzielność ze związkiem bezpośredniego uzupełniania ${ }^{6}$. Takie uzupełnianie zachodzi wtedy, gdy pewien byt nie tylko potrzebuje do istnienia drugiego bytu, lecz także wymaga, aby ten drugi byt go dopełnil, żeby go w pewien sposób „przeniknął”. Skoro już używamy metafor, to posłużmy się Fregowską metaforą nasycania: uzupełnienie polega na nasyceniu jednego bytu przez drugi, na jakimś dookreśleniu go. Z takiego nasycenia wynika niesamodzielność nasyconego bytu, ale nie na odwrót. Może być jednak tak, że jakiś przedmiot $a$ jest uzupełniony przez $b$, a $b$ jest uzupełnione przez $c$. Wtedy $a$ niekoniecznie jest uzupełnione przez $c$ (choć mogą być takie przypadki), ale mimo to powstaje całość $(a, b, c)$, której elementy są powiązane „łańcuchowo” związkiem uzupełniania. Taka całość też jest całością o charakterze formalnym, choć nie wszystkie jej elementy uzupełniają się bezpośrednio. Całość taka okazuje się bardziej konkretna niż owe elementy7.

Typowym przykładem ilustrującym te rozważania są własności jednego przedmiotu. Będę rozumieć je tu jako partykularia. Moja zdolność do trawienia jest niesamodzielna wobec mojej zdolności do chodzenia, choć obie własności wcale się bezpośrednio wzajemnie nie uzupełniają. Każda z nich uzupełnia się jednak bezpośrednio i wzajemnie ze mną jako ich podmiotem, dlatego pozostają w obrębie jednej formalnej całości i są abstraktami, podczas gdy ta całość (tzn. ja jako określony tymi i innymi własnościami) jest konkretem. Podob-

\footnotetext{
${ }^{6}$ Uzupełnianie nie jest pojęciem, którego Ingarden explicite używa.

7 Zwracam uwagę na podobieństwo (ale tylko podobieństwo) podanego opisu z Husserlowską definicją całości z Badań logicznych (Husserl 2000: 343).
} 
nie, jeśli uniwersale jest wzajemnie niesamodzielne względem dwóch przedmiotów, to te ostatnie są też względem siebie wzajemnie niesamodzielne.

Dotychczasowe rozważania nie budzą większych wątpliwości, gdy $a$ jest wzajemnie i sztywno niesamodzielne wobec $F$, a $F$ sztywno i wzajemnie niesamodzielne wobec $b$. Realista umiarkowany odrzuca jednak w punkcie wyjścia sztywną niesamodzielność uniwersaliów - gdyby mogły wspólistnieć tylko z jednym przedmiotem, to nie byłyby uniwersaliami. Jeśli nadal twierdzi, że immanencja polega na niesamodzielności, to zostaje mu tylko niesamodzielność rodzajowa. Jej przyjęcie niewiele jednak zmienia, jeśli chodzi o istotę argumentu z oddzielenia (a raczej pierwszego członu zawartego w nim dylematu). Nadal bowiem przedmioty egzemplifikujące to samo uniwersale będą ze sobą współistnieć w obrębie formalnej całości, tyle że niektóre jej składniki będą mogły być wymieniane na inne. Zawsze jednak przedmioty egzemplifikujące jakieś uniwersale będą musiały istnieć wyłącznie w obrębie jakiejś całości zawierającej inne przedmioty egzemplifikujące to uniwersale. W ten sposób lokalny monizm uzyska dodatkową kwalifikację i stanie się monizmem dynamicznym.

Dlaczego jednak mamy zakładać wzajemność niesamodzielności między uniwersale a przedmiotami jednostkowymi? Gdy jej nie założymy, argument z oddzielenia upada. Rzecz jasna, realista umiarkowany przyjmuje, że uniwersale jest niesamodzielne wobec przedmiotów (inaczej musiałby przejść na pozycje platońskie), ale czy musi uznawać odwrotną niesamodzielność? Uważam, że niesamodzielność, wtedy gdy jest oparta na bezpośrednim uzupełnianiu, musi być w pewnym szczególnym sensie wzajemna. Mianowicie, jeśli $x$ jest sztywno bądź rodzajowo niesamodzielny wobec $y$, tak że $y$ uzupełnia $x$, to $y$ jest co najmniej rodzajowo niesamodzielny wobec $x$ (a właściwie wobec dowolnego przedmiotu należącego do tego samego rodzaju co $x$ ). Jeśli bowiem $x$ potrzebuje uzupełnienia przez $y$, to $x$ tworzy z $y$ bezpośrednią całość w sensie formalnym. Znaczy to tyle, że $y$ również pozostaje $\mathrm{w}$ obrębie tej całości. Jeśli jednak $y$ byłby samodzielny wobec $x$, to nie mógłby takiej całości z nim tworzyć, a mógłby jedynie być z nim złączony regularną relacją. Wtedy $x$ tworzyłby z $y$ całość formalną, a $y$ z $x$ całość sumatywną. Jest to nie do przyjęcia, dlatego też niesamodzielne byty pozostające $\mathrm{w}$ związku uzupełniania muszą być przynajmniej rodzajowo wzajemnie niesamodzielne. A przecież uniwersale i przedmiot jednostkowy pozostaje ze sobą w związku uzupełniania.

Realista umiarkowany może podnieść jeszcze jedną kwestię. Może zauważyć, że niesamodzielność rodzajowa także nie nadaje się do interpretacji immanencji powszechnika. Owszem, powie, powszechnik musi tworzyć całość formalną z przedmiotami jednostkowymi, ale wcale nie jest konieczne, aby przedmiot, który przestaje egzemplifikować dany powszechnik, był zastępowa- 
ny przez inny przedmiot tego samego rodzaju. W ogóle większość powszechników nie jest przypisana do określonych rodzajów: rzeczy czerwone mogą należeć do zupełnie radykalnie odmiennych rodzajów. Ponadto, do swego istnienia powszechnik wymaga tylko jednego przedmiotu, który go egzemplifikuje, a więc te, które przestają go egzemplifikować, wcale nie muszą być wymieniane na inne, dopóki istnieje przynajmniej jedna egzemplifikacja. Chodzi bowiem nie tyle o to, aby powszechnik aktualnie był egzemplifikowany przez wiele rzeczy, ile aby mógł być egzemplifikowany przez wiele, choć aktualnie może być egzemplifikowany tylko przez jedną. Mogłoby się zdarzyć, że w świecie pozostałby tylko jeden przedmiot czerwony, a wszystkie inne przedmioty czerwone zmieniłyby barwę. Ale skoro tak, to przedmiot ów wcale nie musiał (przed ową zmianą barwy przez pozostałe) wspólistnieć z innymi przedmiotami czerwonymi w obrębie formalnej całości. Jest więc samodzielny wobec nich, choć pozostaje jakoś niesamodzielny wobec czerwieni, a czerwień wobec niego. Wydaje się, że taka możliwość obala argument z oddzielenia.

W odpowiedzi na to należy zauważyć, że wówczas bardzo podejrzana staje się owa ciągle postulowana niesamodzielność powszechnika, która ma nie być ani sztywna, ani rodzajowa. Jeśli wciąż mamy w świecie dwa przedmioty czerwone, to z którym z nich czerwień musi współistnieć w obrębie formalnej całości? Nie można odpowiedzieć, że z dwoma, jeśli przyjmujemy przedstawioną wyżej opowieść. $W$ takim razie tylko z jednym, przy czym jest zupełnie dowolne, który to przedmiot. Jeśli jednak tak, to czerwień jest uzupełniana tylko przez jeden $\mathrm{z}$ tych przedmiotów, a ten drugi wcale jej nie uzupełnia. Znaczy to jednak tyle, że ów przedmiot wcale nie jest jej podmiotem. Jej wymaganie, aby istnieć $\mathrm{w}$ podmiocie, jest spełnione tylko przez jeden przedmiot czerwony, choć jest zupełnie dowolne który. Jaką jednak funkcję pełni wtedy wobec czerwieni drugi przedmiot i jaką funkcję ona pełni wobec niego? Skoro ów drugi przedmiot nie jest $\mathrm{w}$ istocie podmiotem czerwieni, to $\mathrm{i}$ ona nie jest jego własnością: nie zachodzi tu wzajemne uzupełnianie się. Wtedy można zapytać, jaka jest racja tego, że czerwień musi współistnieć z jednym (dowolnym) przedmiotem, a z innymi czerwonymi przedmiotami już nie. Jak widać, można wprawdzie obalić argument $\mathrm{z}$ oddzielenia, twierdząc, że uniwersale jest niesamodzielne tylko wobec jednego, dowolnego przedmiotu, który je egzemplifikuje, ale refutacja taka dokonuje się za zbyt wielką cenę.

Rojek chyba zdaje sobie sprawę z zagrożenia lokalnego monizmu, ponieważ twierdzi, że argument z oddzielenia ,słusznie jednak wskazuje, że istnienie wspólnych własności, które miałyby być ogólnie [tzn. rodzajowo] niesa-

${ }^{8}$ Analogiczny problem nie powstaje w przypadku niesamodzielności rodzajowej. Muszę współistnieć z jakimś kształtem i może to być kształt dowolny (w pewnych granicach), ale zawsze współistnieję tylko z jednym kształtem i wtedy uzupełniamy się nawzajem. 
modzielne wobec rzeczy, wymaga poluzowania nałożonych przez Ingardena warunków niesamodzielności” (Rojek 2019: 134). Na czym jednak takie poluzowanie niesamodzielności miałoby polegać? Chyba tylko na tym, że neguje się przynajmniej jeden $\mathrm{z}$ trzech definicyjnych warunków niesamodzielności: (1) konieczność wspólistnienia (2) w obrębie całości (3) zjednoczonej związkami formalnymi. Poluzowanie niesamodzielności polegające na zanegowaniu jakiegokolwiek z tych warunków skutkowałoby zastąpieniem niesamodzielności czymś innym: albo zupełnym brakiem uwarunkowania egzystencjalnego (negacja 1), albo zależnością bez konieczności tworzenia jakiejkolwiek całości $\mathrm{z}$ bytem warunkującym (negacja 2), albo zależnością zachodzącą w obrębie całości sumatywnej (negacja 3). Rojek zdaje się wybierać tę trzecią możliwość:

trzeba uznać, że całości, tworzone przez własności i rzeczy, choć mają charakter formalny, nie muszą być „niezapośredniczone”, czyli mogą zajmować odrębne miejsca. $\mathrm{Z}$ punktu widzenia mereologii nie ma z tym problemu, bo całość nie musi wcale obejmować wyłącznie części graniczących ze sobą. Możemy mówić o całości wody we wszechświecie niezależnie od tego, że jej poszczególne porcje są oddzielone jedna od drugiej (Rojek 2019: 134-135).

Otóż charakterystyka ta wydaje się niespójna, o ile niekonieczność niezapośredniczenia rozumie się jako możliwość istnienia regularnych relacji między rzeczami tworzącymi całość. A to chyba Rojek zakłada - relacje przestrzenne z pewnością nie są związkami formalnymi. Jednak wtedy całość ta wcale nie ma charakteru formalnego, lecz relatywny - taka właśnie jest przywołana w cytacie całość złożona z porcji wody i to nawet wtedy, gdy porcje te graniczą ze sobą. Rojek stosuje kategorie przestrzenne do omawianej tu postaci argumentu z oddzielenia, a nie to jest w nim istotne. Poluzowanie niesamodzielności jest po prostu rezygnacją z niej, a więc również rezygnacją z realizmu umiarkowanego i przejściem do jakiegoś stanowiska, które postuluje co najwyżej zależność uniwersale od przedmiotu jednostkowego.

\subsection{ABSURD (DOSŁOWNEGO) ZWIELOKROTNIENIA POWSZECHNIKA}

Przejdźmy teraz do drugiej części dylematu. Jeśli odrzucamy lokalny monizm i twierdzimy, że rzeczy egzemplifikujące tę samą wspólną własność wcale nie są względem siebie niesamodzielne, to musimy przyznać, że owa własność jest samodzielna względem samej siebie. Ciągle bowiem zakładamy, że uniwersalia są wieloznacznie i wzajemnie niesamodzielne wobec przedmiotów jednostkowych. Niech $a$ i $b$ egzemplifikują $F$. Wtedy $a$ tworzy z $F$ całość formalną i $b$ tworzy z $F$ całość formalną. Stwierdzenie, że $a$ i $b$ są względem siebie samodzielne, oznacza nie tylko, że $a$ i $b$ wzajemnie się nie uzupełniają, lecz także że nie istnieje formalna całość $(F, a, b)$. Aby zachodziło to ostatnie, 
musimy rozerwać któryś ze związków między $a, b$ i $F$. Nie możemy zrezygnować z niesamodzielności między $a$ i $F$, nie możemy też zrezygnować z niesamodzielności między $b$ i $F$. Jedyna możliwość, jaka zostaje, to tak pojąć $F$, aby nie mogło ono być tym elementem, dzięki któremu powstaje całość $(F, a, b)$, jednakże przy zachowaniu wspomnianej niesamodzielności między $F$ i oboma przedmiotami jednostkowymi. Jedyny sposób dokonania tej sztuki to zanegowanie zwrotności niesamodzielności. Wtedy można powiedzieć, że mimo iż $a$ jest wzajemnie niesamodzielne wobec $F$, a $F$ wobec $b$, to i tak nie powstaje całość $(F, a, b)$, ponieważ $F$ jest samodzielne względem siebie samego, tzn. nie tworzy z sobą samym całości formalnej. To ostatnie jednak jest absurdalne, ponieważ jest wprost zaprzeczeniem istotnej jedności przedmiotu. Trudno wyobrazić sobie większą niesamodzielność niż tę opartą po prostu na formalnym związku identyczności z samym sobą.

Rojek przyznaje, że niesamodzielność jest zwrotna, nie będę więc dodatkowo argumentowal na rzecz tej tezy. Jednocześnie twierdzi, że realista umiarkowany może przyjąć tezę o niesamodzielności własności wobec samej siebie, nawet jeśli owa własność jest dosłownie wspólna dwom wzajemnie samodzielnym przedmiotom. W świetle dotychczasowych analiz trudno to zrozumieć. Rojek uważa, że podniesione wyżej problemy da się przezwyciężyć w ten sam sposób, w jaki starał się przezwyciężyć zarzut monizmu - przez poluzowanie niesamodzielności. Jednakże odpowiedź Rojka, dosłownie rozumiana, jest wewnętrznie sprzeczna. Najpierw przyznaje, że wspólna własność, tak jak każda rzecz, „z konieczności wspólistnieje ze sobą i tworzy ze sobą całość o charakterze formalnym" (Rojek 2019: 135), aby pięć wierszy niżej szukać rozwiązania omawianej trudności w negacji absolutnego, czyli formalnego, charakteru owej całości: „trudność polega tylko na zakładanym [...] absolutnym charakterze całości".

Zauważmy ponadto, że jeżeli wspólna własność tworzy całość z samą sobą, ale jak chce Rojek, nie jest to całość absolutna (formalna), to wtedy własność musi chyba tworzyć ze sobą całość sumatywną. Musi więc być jej wiele - choć taka teza już na poziomie czysto werbalnym wydaje się absurdalna. Całość sumatywna w sensie Ingardenowskim musi mieć co najmniej dwie części właściwe. Skoro tak, to własność musi tworzyć całość ze swoim zwielokrotnieniem. W istocie Rojek mógł od razu powiedzieć, że argument $\mathrm{z}$ oddzielenia nawet $\mathrm{w}$ nowej formule nie zagraża wspólnym własnościom, ponieważ taka własność, mimo że jest jedna, to jest jej wiele. Jest jednością, a zarazem mnogością. Rzeczywiście można znaleźć miejsce, gdzie Rojek wprost coś takiego twierdzi: „można uznać, że istnienie jedności w wielości świadczy o istnieniu bytów, które są rzeczywiście czymś, co może być czymś jednym i mnogim zarazem [...]. To [...] rozwiązanie jest przyjęciem realizmu w kwestii uniwersa- 
liów" (Rojek 2019: 26). Jeśli mają istnieć formalne całości $(F, a)$ oraz $(F, b)$, ale nie może być formalnej całości $(F, a, b)$, to trzeba po prostu oddzielić $F$ od samego $F$. Jeśli rzeczywiście na tym miałby polegać realizm, to byłby stanowiskiem tak dalece modyfikującym sens słów „jedność” i „tożsamość”, że uniemożliwiałoby to racjonalną dyskusję.

Aby uniknąć tego typu aporii, należy uznać transcendencję powszechników. Wiąże się ona $\mathrm{z}$ ich pozaczasowym i nieprzestrzennym sposobem istnienia. Rojek, za Jamesem P. Morelandem, oddziela jednak problem transcendencji od problemu istnienia poza czasoprzestrzenią i twierdzi, że możliwe są idealne (to jest istniejące poza czasem i przestrzenią) uniwersalia, które są immanentne rzeczom czasoprzestrzennym (Rojek 2019: 55-57). Moreland (a Rojek cytuje go aprobująco) rozumie jednak czasoprzestrzenność jako posiadanie wymiarów czasoprzestrzennych, a więc jako posiadanie części przestrzennych i/lub czasowych. Widać to $\mathrm{w}$ jego charakterystyce idealności związku egzemplifikacji: ma on być nieprzestrzenny dlatego, że własność nie zawiera się w przedmiocie jak piasek w wiaderku (Moreland 2001: 19). Ten ostatni sposób zawierania się jest jednak możliwy tylko wtedy, gdy oba człony związku zawierania mają wymiary przestrzenne, co z kolei wiąże się z posiadaniem części przestrzennych. Oczywiście prawdą jest, że związek między przedmiotem a własnością (nazywany przez Morelanda egzemplifikacją i utożsamiany ze związkiem między indywiduum a powszechnikiem) nie jest czasoprzestrzenny w tym sensie. Nieposiadanie części przestrzennych i/lub czasowych nie gwarantuje jednak jeszcze braku czasoprzestrzennego określenia - a ono decyduje o czasoprzestrzenności. Gdyby gwarantowało, to punkty istniałyby poza przestrzenią, a substancje (enduranty) byłyby pozaczasowe. Tymczasem punkty są przestrzennie określone mimo swego nierozciągłego charakteru, a substancje są czasowo określone mimo braku faz czasowych. Dlatego punkty istnieją w przestrzeni, a substancje w czasie. Podobnie uniwersalia, tak jak je rozumie Moreland, mimo że nie miałyby czasoprzestrzennej rozciągłości, to jednak dzięki immanencji w rzeczach fizycznych nabywałyby czasoprzestrzennego określenia i przestałyby być idealne.

\section{ZWIĄZEK MIĘDZY UNIWERSALIAMI A PARTYKULARIAMI}

Problem jednak w tym, czy transcendencja platońskich uniwersaliów pozwala im warunkować podobieństwo własności i istot rzeczy. Rojek uważa, że nie, i swą tezę ilustruje przykładem ontologii Ingardena. Próbując opisać stosunek czystych jakości do jednostkowych istot i własności (konkretyzacji czystych jakości), Ingarden poczynił uwagi, które w ostatecznym rozrachunku 
mają charakter negatywny. Po pierwsze, twierdzil, że czyste jakości są silnie strukturalnie transcendentne wobec partykulariów (jednostkowych natur i własności), a więc że są wobec nich w pełni samodzielne. Oczywiście, jednostkowe jakości są również samodzielne wobec jakości idealnych. Po drugie, jakości są radykalnie transcendentne, tzn. nie mogą być w żaden sposób zmienione na skutek działań partykulariów. Konkretyzacja jakości nie może w związku z tym oznaczać przejścia jakości ze sfery idealnej do sfery bytów jednostkowych (Ingarden 1987b: 246-247)9. Nie może też być żadną relacją przyczynową, jako że ta zachodzi tylko między zdarzeniami, a zdarzenia są określone czasowo. Ingarden utrzymuje również tezę o niezależności jakości idealnych od ich konkretyzacji. Zakłada ponadto, że czyste jakości warunkują swe konkretyzacje. W kontekście tezy o silnej transcendencji strukturalnej Ingarden twierdzi, że między jakościami a partykulariami nie zachodzą związki bytowe, a jedynie relacja odpowiedniości. Rojek wyraźnie rozumie relację odpowiedniości jako obustronnie niekonieczną dla swych członów, jako „zewnętrzne przyporządkowanie”, i wyprowadza stąd wniosek, że z tego względu czyste jakości nie mogą w żaden sposób warunkować jednostkowych istot i własności, a w szczególności nie mogą być podstawą podobieństwa między nimi (Rojek 2019: 164-165).

Odpowiadając na ten zarzut, trzeba przede wszystkim wskazać kontekst, w którym Ingarden głosi tezę o odpowiedniości. Chce on podkreślić transcendencję jakości idealnych i to, że zawarta w jednostkowych własnościach treść (materia) nie jest samą jakością idealną, lecz właśnie jej jednostkowym odpowiednikiem. W tym zakresie teza Ingardena o odpowiedniości jest podobna do tezy Lewisa, że nie zachodzi międzyświatowa identyczność, a jedynie odpowiedniość przedmiotów z jednego świata i jego „sobowtórów” zamieszkujących inne światy. O ile jednak Lewis łączy tezę o odpowiednikach z tezą o zupełnej izolacji światów, o tyle analogiczna teza dotycząca stosunku partykulariów do jakości idealnych nie musi być wprowadzona do systemu Ingardena. Twierdząc, że nie zachodzi między nimi związek bytowy, Ingarden nie ma wcale na myśli pełnej izolacji. „Związek bytowy” należy rozumieć w kontekście rozważań o transcendencji strukturalnej: między jakościami a ich konkretyzacjami nie zachodzi związek bytowy zakładający niesamodzielność, a więc taki, który formalnie wiąże ze sobą zasięgi bytowe idealnych jakości i jednostkowych własności w formalną całość. To nie wyklucza jednak zachodzenia innych związków, takich jednakże, które zakładają co najwyżej zależność. Jaki jest charakter tej zależności?

\footnotetext{
9 Ingarden mówi w tym miejscu o stosunku przedmiotów indywidualnych do idei, ale
} to samo można powiedzieć o stosunku jednostkowych istot i własności do czystych jakości. 
Platonik musi twierdzić, że jednostkowe własności i istoty mają charakterystyczną dla siebie treść (czyli są np. jednostkowym człowieczeństwem lub czerwienią) dzięki związkowi z czystymi jakościami idealnymi. Czerwień pomidora jest czerwienią właśnie dlatego, że jest konkretyzacją czystej czerwieni. Ważne jest jednak, że jednostkowa własność bycia czerwonym jest samoistna w sensie Ingardena, a więc że jednostkowa czerwień (tj. jednostkowa jakość) jest rzeczywiście zawarta w jednostkowej własności bycia czerwonym bądź też rzeczywiście ją konstytuuje. Nie można zależności jednostkowych własności od idealnych jakości rozumieć w ten (absurdalny) sposób, że własności same w sobie są bezjakościowe ${ }^{10}$. Nie można bycia czerwonym rzeczy jednostkowej sprowadzać do związku tej rzeczy z czystą jakością idealną. Konkretyzacja czystej jakości musi polegać między innymi na pojawieniu się nowej treści jednostkowej, będącej niejako odzwierciedleniem czystej jakości. To jednostkowa jakość czerwieni czyni rzecz czerwoną. Natomiast ta jednostkowa jakość jest uwarunkowana przez jakość idealną. Mając to na uwadze, można zaryzykować hipotezę, że Ingarden używał słów „odpowiedniość” i jemu pokrewnych nie tyle w sensie „zewnętrznego przyporządkowania”, ile w celu podkreślenia, że jednostkowe własności mają pewną treść, która jest „sobowtórem” (właśnie odpowiednikiem) czystej jakości, ale jest przez nią w tym byciu „sobowtórem” uwarunkowana.

Czysta jakość nie może oczywiście być w ten sam sposób uwarunkowana przez swoje konkretyzacje: idealna czerwień jest czerwienią dzięki samej sobie, a nie dzięki związkowi z jednostkowymi czerwieniami. Jakości idealne są czyste między innymi w tym sensie, że do bycia tą treścią, którą są, nie potrzebują niczego innego. Stąd związek idealnych jakości z ich konkretyzacjami jest jednostronnie konieczny.

Dlatego też związku między własnościami jednostkowymi a czystymi jakościami nie można sprowadzić do takiego podobieństwa, jakie zachodzi między samymi jednostkowymi własnościami. Czerwień pomidora będzie czerwienią nawet wtedy, gdy czerwień papryki przestanie istnieć, dlatego że czerwień pomidora, choć jest podobna do czerwieni papryki, nie jest przez nią uwarunkowana. $\mathrm{Z}$ drugiej strony, podobieństwo czerwieni jednostkowej do czerwieni

${ }^{10}$ Rojek (2019: 166) zdaje się przypisywać taką tezę platonikom. Jest ona echem karykaturalnej wizji platonizmu przedstawionej przez Davida Armstronga, zgodnie z którą jest to stanowisko polegające na umieszczeniu całej jakościowej treści przedmiotów w platonskim „miejscu ponadniebnym”. Taki platonizm łatwo potem triumfalnie obalić. Armstrong tworzy jednak swą wizję platonizmu, przyjmując założenie, którego nie przyjmują platonicy: że związek między partykulare a uniwersale to związek między przedmiotem a jego własnością. Nic więc dziwnego, że tezę o transcendencji uniwersaliów pojmuje jako tezę o transcendencji własności przedmiotów indywidualnych (por. Armstrong 1978: 64-76). 
idealnej nie może opierać się na ich uczestniczeniu w innej idealnej jakości, ponieważ wtedy prowadziłoby to do regresu (słynny „trzeci człowiek”). Podobieństwo jednostkowej własności do jakości idealnej musi być ugruntowane w jakimś pierwotniejszym związku, ale musi być to związek między tymi dwoma bytami, tzn. samą jednostkową własnością i czystą jakością. Musi on być asymetryczny i nie może zachodzić między samymi jednostkowymi własnościami, ponieważ wtedy należałoby porzucić platonizm na rzecz nominalizmu tropowego ${ }^{11}$.

Twierdzenie, że poszukiwany związek jest jednostronnym uwarunkowaniem treści jednostkowej własności przez czystą jakość, jest jednak dość ubogie, ponieważ taka charakterystyka jest jedynie egzystencjalno-formalna (lub tylko formalna). Jestem pesymistą co do ludzkich możliwości odkrycia natury takiego związku. Wydaje się jednak, że można przybliżyć się do jego zrozumienia przez analizę pewnych metafor, które być może w jakimś stopniu oddają jego naturę. Nie chcę oczywiście twierdzić, że takie filozofowanie „z wnętrza metafory" może zastąpić prawdziwy filozoficzny wgląd. Kiedy jednak ten ostatni jest niemożliwy z powodu naszych ograniczeń, musimy zadowolić się pewnymi modelami.

Często mówi się, że platońskie uniwersalia są wzorami partykulariów. Oczywiście żaden przedmiot fizyczny nie może być wzorem dla innych przedmiotów fizycznych w tym samym sensie w jakim uniwersale jest wzorem. W szczególności żadna rzecz fizyczna nie stanowi koniecznej podstawy podobieństwa innych rzeczy fizycznych. Nie jest też tak, że rzeczy fizyczne odnoszą się w dokładnie taki sam sposób do swego fizycznego prototypu - zawsze te relacje są nieco inne, dlatego rzeczy fizyczne nie są uniwersaliami. Ale zauważmy, że gdy mamy prototyp i na jego podstawie wykonujemy kopie, to prototyp w jakiś słaby sposób przyczynia się do zaistnienia kopii, choć nie na odwrót. Kopie są podobne do prototypu, ale to podobieństwo ma swą podstawę w fakcie, że to one zostały wytworzone na wzór prototypu, a nie na odwrót. Wiadomo, że te relacje są przygodne i dotyczą tylko zaistnienia, a nie dalszego trwania kopii, ale już analiza takiego prostego przykładu nasuwa jakieś intuicje w sprawie stosunku jednostkowej własności do jakości idealnej. Jednostkowa własność jest podobna do jakości idealnej, ponieważ ją jakoś odwzorowuje. To jednostronne, asymetryczne odwzorowanie jest podstawą symetrycznego podobieństwa jednostkowej własności do czystej jakości i podstawą podobieństwa między jednostkowymi własnościami odwzorowującymi tę samą czystą jakość. Dzięki temu odwzorowaniu własność jest istotnie tym, czym jest. Po-

${ }^{11}$ Być może tak właśnie należy zrobić, ale zgodnie z zapowiedzią nie będę tej sprawy rozstrzygał. 
nieważ jednak nie może istnieć, nie będąc sobą, to jest również egzystencjalnie zależna od czystej jakości (wbrew temu, co mówi Rojek).

Być może lepszą metaforą byłoby odzwierciedlanie: moje odbicie odzwierciedla mnie samego i jest to jedną z racji jego zaistnienia i dalszego trwania, a także racją podobieństwa odbicia do mnie oraz racją podobieństwa różnych moich odbić (w różnych lustrach). Warunkuje również moje odbicie w aspekcie tego, czym ono jest - ono jest istotnie moje. Znów nie mamy tu pełnej analogii (i nie możemy mieć) - związek między odbiciem a mną nie jest bezpośredni, odbicie do istnienia potrzebuje również lustra, które w żaden sposób od niego i ode mnie nie zależy, różne odbicia pozostawałyby w nieco innych relacjach do mnie samego itd. Niemniej pewna idealizacja tych intuicji może pomóc przybliżyć się do ujęcia natury związku między uniwersaliami a partykulariami.

Ponieważ związek konkretyzacji jakości z samą jakością idealną jest konieczny dla owej konkretyzacji, to bezpodstawny okazuje się również inny zarzut Rojka przeciw platonizmowi. Rojek, za Gustavem Bergmannem i Edwardem Swiderskim, twierdzi, że platonizm zawodzi również jako rozwiązanie problemu występowania związków koniecznych w rzeczach jednostkowych (Rojek 2019: 165-166). W myśl tego argumentu, nawet jeśli czyste jakości wyznaczają związki konieczne, w jakich pozostają ich konkretyzacje składające się na przedmiot, to w dziedzinie partykulariów związki te nie są konieczne, ponieważ partykularia są jedynie zewnętrznie przyporządkowane jakościom idealnym ${ }^{12}$. W zarysowanej przeze mnie wersji platonizmu ta ostatnia przesłanka jest fałszywa. Owszem, związek partykularnej jakości (natury lub własności) z czystą jakością jest przygodny, o ile sama partykularna jakość jest przygodna i nie musi istnieć. Gdy nie istnieje, nie zachodzą jednak w niej żadne związki i problem wskazany przez Rojka wcale nie powstaje. Problem ten powstawałby, gdyby nie było konieczności w tym, że partykularna własność odpowiada pewnej jakości idealnej, a więc gdyby na przykład owa własność mogła przestać odpowiadać jednej jakości, a zacząć odpowiadać innej. To jest jednak niemożliwe z racji wskazanej jednostronnej zależności partykularnej własności od czystej jakości.

\footnotetext{
${ }^{12}$ Rojek zakłada, że czyste jakości nie tyle wyznaczają związki konieczne, ile pozostają w związkach koniecznych z innymi jakościami. To twierdzenie powoduje jednak rozliczne trudności. Nie może być bowiem tak, że np. idealna czerwień rzeczywiście charakteryzuje pewną idealną rozciągłość. W tej ostatniej musiałyby bowiem tkwić również i inne barwne jakości idealne, a przecież owa rozciągłość jest jedna, a te jakości się wykluczają. Dość powiedzieć, że dla Ingardena w zawartości idei (a to one są odpowiedzialne za związki konieczne) też nie dochodzi do idealnej realizacji związków miedzy idealnymi odpowiednikami czystych jakości. Czyste jakości są niejako ułożone „obok siebie” jako części zawartości. Argument Rojka można jednak przeformułować, tak żeby dotyczył również sytuacji, w której zachodzi jedynie wyznaczanie związków koniecznych.
} 
Platonizm w kwestii uniwersaliów nie stoi więc na przegranej pozycji. Jest stanowiskiem realistycznym o wiele bardziej spójnym niż realizm umiarkowany. Osobną kwestią jest jego prawdziwość. To jest jednak temat na inny, znacznie obszerniejszy tekst.

\section{BIBLIOGRAFIA}

Armstrong D. M. (1978), Universals and Scientific Realism, t. 1: Nominalism and Realism, Cambridge: Cambridge University Press.

Husserl E. (2000), Badania logiczne, t. 2.1, tłum. J. Sidorek, Warszawa: Wydawnictwo Naukowe PWN.

Ingarden R. (1987a), Spór o istnienie świata, t. 1, Warszawa: Państwowe Wydawnictwo Naukowe.

Ingarden R. (1987b), Spór o istnienie świata, t. 2.1, Warszawa: Państwowe Wydawnictwo Naukowe.

Luc J. (2020) W gąszczu filozoficznych rozróżnień. Pawła Rojka systematyzacja podstawowych zagadnień dotyczqcych tropów i uniwersaliów, „Filozofia Nauki” 28(2) [110], 99-111.

Moreland J. P. (2001), Universals, Chesham: Acumen.

Piwowarczyk M. (2014), Krytyka realizmu immanentnego $w$ kwestii uniwersaliów - argument z oddzielenia, „Filozofia Nauki” 22(4) [88], 109-130.

Piwowarczyk M. (2015), Podmiot i własności. Analiza podstawowej struktury przedmiotu, Lublin: Wydawnictwo KUL.

Piwowarczyk M. (2020), Two Models of the Subject-Properties Structure, „Axiomathes” (w druku). DOI: https://doi.org/10.1007/s10516-019-09463-w

Rojek P. (2019), Tropy i uniwersalia. Badania ontologiczne, Warszawa: Wydawnictwo Naukowe Semper.

Rosiak M. (2012), Awantury i wybryki analitycznej metafizyki, „Diametros” 33, 138-157. 